\title{
Aktivitas Antioksidan, Kadar Air, Nilai pH dan Total Fenolik Dendeng Sapi yang di Curing Menggunakan Ekstrak Rosella (Hibiscus sabdariffa L.)
}

Elisa M. N. Wete ${ }^{\mathrm{a}}$, Stefanus $\mathrm{Sio}^{\mathrm{b}}$ dan Kristoforus W. Kia

${ }^{a}$ Fakultas Pertanian, Universitas Timor, Kefamenanu, TTU-NTT, 85613, Indonesia, email : elisamargaretanoviawete17@gmail.com

${ }^{b}$ Fakultas Pertanian, Universitas Timor, Kefamenanu, TTU-NTT, 85613, Indonesia, email : stefsio67@gmail.com

${ }^{c}$ Fakultas Pertanian, Universitas Timor, Kefamenanu, TTU-NTT, 85613, Indonesia, email : willykia71@yahoo.co.id

\section{Article Info}

\section{Article history:}

Received 29 Mei 2019

Received in revised form 20 September 2019 Accepted 23 Oktober 2020

DOI:

https://doi.org/10.32938/ja.v4i4.705

Keywords:

Dendeng sapi

Antioksidan

Kadar air

Kandungan fenolik

$\mathrm{pH}$

\section{Pendahuluan}

Bahan pangan adalah bahan baku yang berasal dari hasil pertanian, berupa nabati dan juga dari hewani yang digunakan oleh industri pengolahan pangan untuk menghasilkan suatu produk pangan, salah satu bahan pangan yaitu daging. Daging merupakan salah satu sumber protein hewani yang tingg akan nilai gizinya dibandingkan dengan protein nabati, namun daging juga merupakan bahan pangan yang mudah rusak, karena disebabkan oleh adanya aktivitas mikroba didalam bahan pangan itu sendiri. Oleh karena itu untuk mengatasi hal tersebut diperlukan penanganan pengolahan daging yang sesuai yaitu daging diolah menjadi dendeng (Abustam, 2000). Dendeng merupakan produk makanan berbentuk lempengan yang terbuat dari irisan atau gilingan daging sapi segar atau daging sapi beku yang telah diberi bumbu-bumbu lalu dikeringkan. Dendeng umumnya memiliki komposisi gizi yang cukup baik dan rasa yang lezat dan harganya pun relatif mahal. Pembuatan dendeng merupakan salah satu alternatif pengolahan bahan pangan agar masa simpannya relatif lebih lama.

Dalam proses pembuatannya, dendeng biasanya dicuring. Curing merupakan tahapan dari pengolahan daging yang biasa dilakukan oleh industri pembuatan dendeng dengan tujuan untuk pengawetan. Pada proses curing biasanya ditambahkan bahan preservatif seperti garam, natrium nitrit dan bumbu-bumbu untuk menambah cita rasa. Dendeng biasa disaji dengan cara digoreng, namun demikian penggorengan produk ini dapat menimbulkan reaks oksidasi lemak yaitu suatu reaksi perubahan pada bahan pangan. Kerusakan akibat proses oksidasi lemak menyebabkan turunnya nilai gizi dan rusaknya cita rasa produk pangan yang dihasilkan. Oleh karena itu perlu adanya pencegahan pada reaksi oksidasi tersebut. Pencegahan yang dapat dilakukan yaitu dengan penambahan bahan yang mengandung antioksidan, salah satunya yaitu nitrit. Nitrit merupakan bahan tambahan pangan yang sering digunakan pada skala komersil sebagai antioksidan untuk mempertahankan warna merah daging. Namun nitrat dan nitrit sebagai pengawet makanan yang diizinkan perlu diperhatikan penggunaannya dalam makanan agar tidak melampaui batas, sehingga tidak berdampak negatif bagi kesehatan manusia.

Nitrit dapat berikatan dengan asam amino atau amida dan membentuk turunan nitrosamin yang bersifat toksit atau racun (Muchtadi, 2008). Oleh karena itu dalam penelitian ini sangat diperlukan bahan alami yang mengandung antioksidan sebagai pengganti nitrit dalam proses curing dendeng, salah satunya yaitu rosella (Hibiscus sabdariffa L.). Rosella memilik kandungan senyawa fenolik yang berfungsi sebagai antioksidan sebanyak 23,10 mg dalam setiap gram bobot kering kelopak rosella. Didalam kelopak bunga rosella terkandung beberapa zat aktif yaitu gossypetin, antosianin, dan glucosidal hibiscin. Pigmen alami yang memberi warna merah pada kelopak rosella dan bersifat antioksidan yang dapat menghambat radikal bebas yaitu antosianin. Antosianin hanya terdapat pada tanaman dengan warna terang pada setiap bagiannya mulai dari bunga, daun dan buah yang dapat dimakan Pemanfaatan kelopak rosella (Hibiscus sabdariffa L.) sebagai bahan pengawe alami menjadi sangat menarik bagi peneliti untuk dikaji.

\section{Metode}

2.1 Waktu dan Lokasi Penelitian

Penelitian ini dilaksanakan di laboratorium MIPA Universitas Widya Mandira (UNWIRA) sejak Februari-April 2019.

\subsection{Alat dan Bahan}

Alat yang digunakan dalam pembuatan dendeng adalah sebagai berikut pisau, talenan, slicer, mangkok, alat tulis, pinset, kamera sendok, piring, cawan arloji, gelas ukur, timbangan digital, gelas beker, tabung reaksi, desikator, labu erlenmeyer, labu takar, buret, bulb, mikropipet, pipet tetes, sudip, dan cawan porselen. Alat untuk uji aktivitas antioksidan yaitu : waterbath, rotary vacum evaporator, kertas saring whatman, alat destilasi, alat titrasi dan spektrofotometer. Sedangkan bahan-bahan yang digunakan dalam pembuatan dendeng ini adalah daging sapi bagianpaha belakang sebanyak $1 \mathrm{~kg}$, yang diperoleh dari Rumah Potong Hewan (RPH) Oeba Kupang, rosella kering $3 \mathrm{~kg}$, dan bumbu-bumbu dapur. Bahan kimia yang digunakan antara lain : aquades, etanol $95 \%$, larutan $\mathrm{NaCl}$ jenuh, asam asetat glasial $\left(\mathrm{CH}_{3} \mathrm{COOH}\right)$, petroleum eter (PE), $\mathrm{HCl}$ pekat, larutan kalium iodida (KI) jenuh, kristal sodium thiosulfat $\left(\mathrm{Na}_{2} \mathrm{~S}_{2} \mathrm{O}_{3}\right)$, larutan $\mathrm{Na}_{2} \mathrm{CO}_{3}{ }^{+}$reagen Folin-Ciocaltue (FC) dan kristal 1,1diphenyl-2-picrylhydrazil ( DPPH).

\subsection{Rancangan Percobaan}

Penelitian ini menggunakan Rancangan Acak Lengkap (RAL) yang terdiri dari 4 perlakuan dan 3 ulangan sehingga terdapat 12 unit percobaan. Perlakuan yang diberikan adalah sebagai berikut:

$\mathrm{R}_{0}$ Daging sapi + bumbu-bumbu (kontrol)

$\mathrm{R}_{1}$ : Daging sapi + bumbu-bumbu + nitrat $200 \mathrm{ppm}$

$\mathrm{R}_{2}$ : Daging sapi + bumbu-bumbu + ekstrak rosella $40 \%$

$\mathrm{R}_{3}$ : Daging sapi + bumbu-bumbu + ekstrak rosella $60 \%$

\subsection{Variabel Penelitian}

Variabel yang diukur dalam penelitian ini adalah aktivitas antioksidan, kadar air, nilai $\mathrm{pH}$, dan kandungan total fenolik dendeng sapi.

\subsection{Analisis Data}

Data yang diperoleh dianalisis dengan metode kurva standar, dengan persamaan regresi linear $\mathrm{y}=\mathrm{bx}+\mathrm{a}$ dibuat berdasarkan data absorbansi dan konsentrasi dari larutan standar menggunakan program Microsoft Excel, kemudian dihitung aktivitas antioksidan dan kadar fenolik total dendeng sapi yang dicuring menggunakan ekstrak rosella.

\section{Hasil dan Pembahasan}

\subsection{Aktivitas Antioksidan Dendeng Sapi}

Antioksidan merupakan suatu senyawa yang berfungsi untuk mencegah dan memperlambat terjadinya proses oksidasi yang menyebabkan kerusakan pada suatu bahan pangan, dalam hal ini bahan pangan tersebut adalah dendeng. Kecepatan kerusakan daging tergantung pada jumlah mikroba. Semakin banyak jumlah mikroba dalam daging maka semakin cepat pula kerusakan yang terjadi. Oleh karena itu untuk mengatasi proses oksidasi dalam daging diperlukan pengolahan dan penambahan antioksidan alami yang berasal dari tanaman salah satunya yaitu rosella. Aktivitas antioksidan dalam penelitian ini diidentifikasi dengan aktivitas penghambatan DPPH (1,1-diphenyl-2-picrylhydrazil) Aktivitas penghambatan DPPH merupakan suatu metode pengukuran aktivitas antioksidan dengan prinsip penstabilan senyawa radikal oleh antioksidan. Hidrogen dari antioksidan berpasangan dengan elektron bebas DPPH membentuk DPPH-H sehingga terjadi perubahan warna dari ungu menjadi kuning pucat (Molyneux, 2004). Senyawa-senyawa yang terdapat dalam buah memiliki peran antioksidan sehingga pengujian total fenol berasosiasi dengan aktivitas antioksidan dalam bahan (Aaby et al. 2012). Hasil penambahan ekstrak kelopak bunga rosella (Hibiscus sabdariffa L.) terhadap nilai aktivitas antioksidan dalam dendeng sapi terlihat pada Tabel 1 .

Hasil pengukuran antioksidan dendeng sapi menggunakan microsoft excel pada Tabel 1 menunjukkan bahwa jenis sampel kontrol negatif (tanpa penambahan nitrat dan ekstrak rosella), pada konsentrasi 25 ppm nilainya 
$66,6 \%$, diikuti dengan konsentrasi $50 \mathrm{ppm}$ yaitu $88,2 \%, 100 \mathrm{ppm}=86,4 \%, 125$ ppm $=86 \%$ dan pada konsentrasi $250 \mathrm{ppm}$ adalah $81,3 \%$.

Tabel 1. Hasil pengukuran rata-rata nilai aktivitas antioksidan dendeng sapi yang dicuring menggunakan ekstrak kelopak bunga rosella.

\begin{tabular}{llccccc}
\hline No & Jenis sampel & \multicolumn{5}{c}{ Aktivitas Antioksidan (\%) } \\
\cline { 2 - 6 } & $25 \mathrm{ppm}$ & $50 \mathrm{ppm}$ & $100 \mathrm{ppm}$ & $125 \mathrm{ppm}$ & $250 \mathrm{ppm}$ \\
\hline 1 & Kontrol Negatif & 66,6 & 88,2 & 86,4 & 86 & 81,3 \\
2 & Kontrol Positif & 54,1 & 85,0 & 85,9 & 84,5 & 78,7 \\
3 & EBR 40\% & 76,2 & 61,0 & 25,2 & 6,1 & Tidak \\
& & & & & terdeteksi \\
4 & EBR 60\% & 61,4 & 27,9 & Tidak & Tidak & Tidak \\
& & & terdeteksi & terdeteksi & terdeteksi \\
5 & Standar & 89,3 & 90,2 & 91,0 & 91,6 & 92,7 \\
\hline
\end{tabular}

Dari hasil ini menunjukkan bahwa pada jenis sampel kontrol negatif tanpa penambahan nitrat dan ekstrak rosella nilai antioksidannya tidak berpengaruh pada dendeng karena nilainya berubah-ubah seiring bertambahnya konsentrasi yang diberi. Kemudian pada jenis sampel kontrol positif dengan penambahan nitrat pada konsentrasi 25 ppm nilainya $54,1 \%$, kemudian meningkat pada konsentrasi $50 \mathrm{ppm}$ dan $100 \mathrm{ppm}$ dengan nilai sebesar $85,0 \%$ dan $85,9 \%$ dan menurun pada konsentrasi $125 \mathrm{ppm}$, dan $250 \mathrm{ppm}$ dengan nilai $84,5 \%$ dan 78,7\%. Dilihat dari konsentrasi 25 ppm, 50 dan 100 ppm ada peningkatan nilai dan nilai tersebut menunjukan bahwa pada jenis sampel kontrol positif dengan penambahan nitrat berpengaruh pada dendeng. Pada jenis sampel dengan penambahan ekstrak rosella $40 \%$ pada konsentrasi $25 \mathrm{ppm}$ yaitu $76,2 \%$ dan menurun pada konsentrasi 50 ppm, 100 ppm, 125 ppm dengan nilai $61,0 \%, 25,2 \%, 6,1 \%$ dan pada konsentrasi 250 ppm nilainya tidak terdeteksi artinya secara kimia nilainya tidak terbaca dalam alat atau bernilai negatif. Kemudian dilanjutkan lagi pada jenis sampel dengan penambahan ekstrak rosella $60 \%$ pada konsentrasi 25 ppm nilainya yaitu $61,4 \%$ kemudian menurun pada konsentrasi 50 ppm yaitu 27,9\%, dan pada konsentrasi 100 ppm, 125 ppm, dan 250 ppm nilainya tidak terdeteksi.

Dilihat dari sampel kontrol positif dengan penambahan nitrat pada konsetrasi 25 ppm nilainya lebih rendah dari pada sampel dengan penambahan ekstrak rosella $40 \%$ dan $60 \%$, jadi pada konsentrasi 25 ppm nilai aktivitas antioksidan tertinggi didapatkan pada sampel ekstrak rosella $40 \%$ dengan nilai $76,2 \%$ kemudian diikuti dengan sampel ekstrak rosella $60 \%$ dengan nilai $61,4 \%$ dan nilai terendah pada konsentrasi 25 ppm didapatkan pada kontrol positif dengan nilai $54,1 \%$. Dilanjutkan pada konsentrasi 50 ppm pada sampel kontrol positif nilainya lebih tinggi yaitu $85,0 \%$ dibandingkan dengan ekstrak rosella $40 \%$ yaitu $61,0 \%$ dan pada ekstrak $60 \%$, nilainya terendah yaitu $27,9 \%$. Pada konsetrasi 100 ppm, 125 ppm dan 250 ppm nilai aktivitas antioksidan tertinggi didapatkan pada sampel kontrol positif dengan penambahan nitrat sebesar $85,9 \%, 84,5 \%$ dan $78,7 \%$ kemudian diikuti dengan sampel ekstrak rosella $40 \%$ dengan nilai $25,2 \%, 6,1 \%$ dan nilai tidak terdeteksi, dan nilai aktivitas antioksidan terendah terdapat pada sampel dengan penambahan ekstrak rosella $60 \%$ yaitu dengan nilai tidak terdeteksi atau bernilai negatif. Nilai tidak terdeteksi pada tabel diatas juga menunjukkan bahwa pada saat konsentrasi naik tidak menunjukkan penurunan absorbansi juga menunjukkan bahwa nilai antioksidan semakin lemah, hal ini diakibatkan karena ekstrak rosella sudah diaplikasikan dengan bahan pangan, yaitu dendeng. Sebelum diaplikasikan pada dendeng nilai antioksidan dalam rosella sangat tinggi lebih tinggi dibandingkan dengan jeruk dan mangga, hal ini sesuai dengan penelitian yang dilakukan oleh Mardiah et al., (2009).

Menurut penelitian yang dilakukan oleh Chang et al,. (2002), bahwa semakin tinggi nilai absorbansi maka akan semakin tinggi pula kemampuan mereduksi, sehingga aktivitas antioksidan semakin besar. Tingginya nilai antioksidan dalam dendeng sapi ini dapat menghambat proses oksidasi yang diakibatkan karena teroksidasinya asam lemak yang ada pada daging, sehingga menyebabkan terjadinya off-flavour pada produk dendeng dan membuat produk dendeng menjadi bau busuk dan tengik. Pengukuran antioksidan dilakukan agar dapat menangkal reaksi radikal bebas penyebab masalah dalam tubuh yang dapat merusak fungsi membran sel. Antioksidan memiliki korelasi yang kuat dengan senyawa fenolik, karena senyawa antioksidan alami sebagian besar adalah senyawa fenolik. Nilai antioksidan juga dapat diuji dengan melihat nilai senyawa fenolik dan nilai $\mathrm{pH}$ dendeng sapi, semakin tinggi nilai senyawa fenolik dan semakin tinggi $\mathrm{pH}$ asam dendeng sapi menunjukkan semakin besar pula antioksidan yang terkandung dalam bahan tersebut. Antioksidan ekstrak rosella $40 \%$ dan $60 \%$ pada penelitian ini menunjukkan nilai yg rendah mungkin dipengaruhi oleh faktor pengeringan dengan oven. Hal ini didukung oleh penelitian yang dilakukan oleh (Rusnayanti, 2018) yang menyatakan bahwa antioksidan dipengaruhi oleh lama proses pengeringan dan semakin panas pengeringan maka aktivitas antioksidan semakin turun, hal ini dikarenakan antioksidan kuat akan rusak oleh panas dan pemasakan.

Di bidang pangan, antioksidan berperan penting untuk mempertahankan mutu produk, mencegah ketengikan, perubahan nilai gizi, perubahan warna dan aroma, serta kerusakan fisik lain yang diakibatkan oleh reaksi oksidasi (Widjaya, 2003). Jika antioksidan dalam produk dendeng yang dihasilkan dari penelitian ini rendah maka akan mengakibatkan terjadinya kerusakan dalam dendeng itu yang disebabkan oleh reaksi oksidasi. Hasil penelitian tentang aktivitas antioksidan lain diduga berasal dari asam-asam organik dan hasil reaksi Maillard yang memiliki kemampuan sebagai antioksidan pula. Hasil serupa ini ditemukan pada penelitian Suryati et al. (2012), bahwa aktivitas antioksidan pada dendeng tidak hanya dipengaruhi dengan penambahan bumbu, tetapi dapat pula disebabkan oleh oksidasi $\mathrm{NO}_{2}$ dari garam nitrit yang ditambahkan dan produk reaksi Maillard. Dalam kaitan dengan aplikasi ini, aktivitas antioksidan yang rendah juga dipengaruhi oleh bahan pangan yang telah diberi antioksidan. Proses panas serta $\mathrm{pH}$ yang diterapkan pada pengolahan pangan mempengaruhi kestabilan aktivitas antioksidan. Menurut Sukhapat et al. (2004) aktivitas antioksidan rosella dipengaruhi oleh $\mathrm{pH}$ (pH 27). Semakin meningkat $\mathrm{pH}$, semakin menurun aktivitas antioksidan. Konsep umum yang selama ini diketahui, adalah semakin banyak senyawa fenolik dalam sampel semakin tinggi aktivitas antioksidan yang dihasilkan. Hal ini sejalan dengan penelitian Tsai et al. (2002) yang menyatakan bahwa aktivitas antioksidan ekstrak rosella memiliki korelasi yang kuat dengan kandungan antosianin. Falade et al. (2005) menyatakan bahwa ekstrak rosella memiliki kandungan vitamin $\mathrm{C}$ yang tinggi. Vitamin $\mathrm{C}$ dikenal sebagai senyawa antioksidan. Hasil ini dimungkinkan karena aktivitas antioksidan tidak hanya disebabkan oleh kandungan fenolik, namun juga dapat disebabkan keberadaan beberapa fitotokimia lain seperti asam askorbat, tokoferol dan pigmen dengan mekanisme sinergis diantaranya turut menentukan aktivitas antioksidan. Semakin tinggi $\mathrm{pH}$, penurunan aktivitas antioksidan semakin besar, jadi nilai aktivitas antioksidan juga berkaitan dengan nilai $\mathrm{pH}$.

\begin{tabular}{cc} 
Tabel 2. Hasil pengukuran sampel standar antioksidan \\
\hline Konsentrasi $(\mathrm{mg} / \mathrm{L})$ & Absorbansi Sampel Standar \\
\hline 25 & 0,091 \\
50 & 0,068 \\
100 & 0,066 \\
125 & 0,062 \\
250 & 0,055 \\
\hline
\end{tabular}

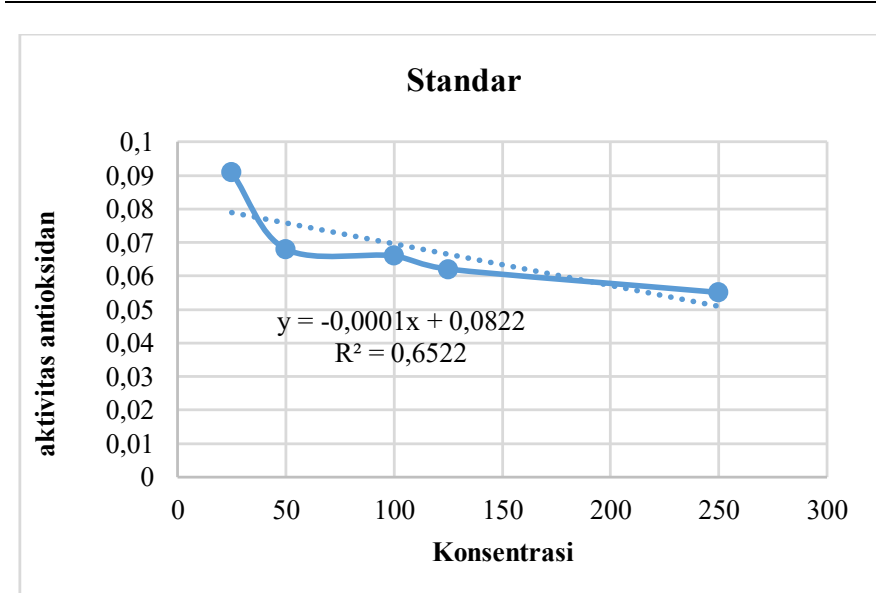

Gambar 1. Kurva linear asam askorbat dengan absorbansi $517 \mathrm{~nm}$

Pada pengujian nilai aktivitas antioksidan, larutan standar yang digunakan adalah asam askorbat dengan variasi konsentrasi $0,50,100,150$, 200, 250. Hasil pengukuran absorbansi pembanding asam askorbat diplotkan terhadap konsentrasinya, sehingga diperoleh kurva linear seperti pada Gambar 1. Nilai $\mathrm{R}^{2}$ yaitu 0,9206 menunjukkan linearitas yang cukup baik, maka persamaan regresi linear $(\mathrm{y}=0,0001 \mathrm{x}-0,0802)$ dapat digunakan untuk penetapan nilai antioksidan sampel bunga rosella (Hibiscus sabdariffa L.)

\subsection{Kandungan Total Fenolik Dendeng Sapi}

Senyawa fenolik merupakan senyawa antioksidan alami yang terdapat dalam bentuk senyawa aktif dalam makanan. Senyawa fenolik dapat mencegah berbagai jenis penyakit, seperti kanker dan jantung koroner. Senyawa ini pun berperan sebagai faktor pelindung terhadap bahaya oksidasi pada tubuh manusia (Widia, 2007). Senyawa fenolik berupa senyawa aromatik, sehingga dapat menunjukkan serapan kuat didaerah spektrum UV. Penambahan ekstrak kelopak bunga rosella (Hibiscus sabdariffa L.) terhadap kandungan total fenolik dalam dendeng sapi setelah dilakukan penelitian terlihat pada Tabel 3.

Tabel 3. Hasil pengukuran rata-rata kandungan fenolik dendeng sapi yang dicuring menggunakan ekstrak kelopak bunga rosella.

\begin{tabular}{clc}
\hline No & Jenis Sampel & Total Fenolik $(\mathrm{mg} / \mathrm{g})$ \\
\hline 1 & Kontrol Negatif & 0,2531 \\
2 & Kontrol Positif & 0,3507 \\
3 & $40 \%$ & 0,3479 \\
4 & $60 \%$ & 0,650 \\
\hline
\end{tabular}

Data pada Tabel 3 menunjukkan bahwa nilai rataan kandungan total fenolik berkisar antara $0,2531 \mathrm{mg} / \mathrm{g}$ sampai dengan $0,650 \mathrm{mg} / \mathrm{g}$. Nilai tertinggi kandungan total fenolik dendeng sapi didapatkan pada jenis sampel $\mathrm{R}_{3}$ dengan penambahan ekstrak rosella $60 \%$ yaitu sebesar $0,650 \mathrm{mg} / \mathrm{g}$ kemudian diikuti dengan sampel $R_{1}$ dengan penambahan nitrat (kontrol positif) dan $R_{2}$ dengan 
penambahan ekstrak rosella $40 \%$ yaitu $0,3507 \mathrm{mg} / \mathrm{g}$ dan $0,3479 \mathrm{mg} / \mathrm{g}$ dan nilai terendah kandungan total fenolik didapatkan pada perlakuan $\mathrm{R}_{0}$ (kontrol negatif) tanpa penambahan nitrat dan ekstrak rosella yaitu $0,2531 \mathrm{mg} / \mathrm{g}$. Semakin tingginya nilai fenolik yang terkandung dalam suatu bahan pangan yaitu dendeng maka senyawa fenolik tersebut dapat berperan dalam memberikan aroma yang khas pada produk makanan itu. Pada sampel $R_{2}$ dengan penambahan ekstrak rosella $40 \%$ nilai senyawa fenolik lebih rendah dibandingkan dengan $\mathrm{R}_{1}$ dengan penambahan nitrat, ini menunjukkan bahwa pada perlakuan $\mathrm{R}_{2}$ dengan penambahan ekstrak rosella $40 \%$ belum efektif untuk meningkatkan nilai senyawa fenolik dendeng sapi karena nilai senyawa fenolik pada konsentrasi $40 \%$ masih rendah dari pada sampel $\mathrm{R}_{1}$ (kontrol positif) dengan penambahan nitrat, oleh karena itu untuk mendapatkan nilai kandungan total fenolik yang lebih baik maka konsentrasi ekstrak rosella yang digunakan dinaikkan konsentrasinya dari 40\% menjadi 50\% mungkin nilai kandungan total fenolik yang dihasilkan lebih tinggi dari penambahan nitrat. Pada sampel dengan penambahan ekstrak rosella $60 \%$ nilai yang didapatkan lebih tinggi dari jenis sampel baik itu kontrol negatif, kontrol positif maupun dengan penambahan ekstrak rosella $40 \%$.

Stabilitas senyawa fenolik dalam ekstrak rosella juga dapat diuji dengan melihat nilai antioksidan dan nilai $\mathrm{pH}$. Jika nilai antioksidannya tinggi dan nilai $\mathrm{pH}$ rendah maka hal tersebut menunjukkan bahwa semakin besar juga nilai kandungan fenolik. Nilai antioksidan pada rosella sendiri sebelum diaplikasikan dalam bahan pangan memiliki nilai antioksidan yang sangat tinggi akan tetapi ketika sudah diaplikasikan dalam bahan pangan nilai antioksidannya menurun. Hal ini diakibatkan karena dalam proses pembuatan dendeng sudah diberi bumbu-bumbu dan juga disebabkan dalam pengujiannya menggunakan larutan DPPH yang telah diencerkan dengan etanol sehingga dapat mengurangi keberadaan nilai antioksidan dalam rosella tersebut. Kandungan fenolik dalam rosella, sebagian besar ditentukan oleh sifat senyawa yang memberi warna ungu kemerahan pada rosella dan bersifat antioksidan yang dapat menghambat radikal bebas yaitu senyawa antosianin. Senyawa ini hanya terdapat pada tanaman dengan warna terang pada setiap bagian rosella. Menurut penelitian yang dilakukan oleh Selim et al. (2008), bahwa kandungan fenolik ekstrak rosella relatif stabil pada $\mathrm{pH}$ 2-4 kemudian menurun pada $\mathrm{pH}$ 6. Ekstrak rosella akan mengalami penurunan persentase total fenolik terbesar pada $\mathrm{pH}$ yang tinggi dibandingkan dengan kondisi $\mathrm{pH}$ yang rendah. Hasil tersebut menunjukkan bahwa pada $\mathrm{pH}$ yang semakin meningkat, ekstrak rosella cenderung mengalami kerusakan sehingga senyawa fenolik yang terkandung didalamnya ikut mengalami kerusakan, ini disebabkan oleh struktur antosianin mudah berubah akibat perubahan $\mathrm{pH}$ dan kekuatan ionik dari larutan yang digunakan. Larutan yang digunakan untuk menguji kandungan senyawa fenolik dalam penelitian ini yaitu larutan $\mathrm{Na}_{2} \mathrm{CO}_{3}{ }^{+}$reagen Folin-Ciocaltue (FC). Pembanding yang digunakan pada penetapan kadar total fenolik rosella merah adalah asam galat. Selain asam galat, asam tanat juga bisa digunakan sebagai pembanding pada penetapan kadar fenolik, karena asam galat memiliki gugus hidroksil 3 sedangkan asam tanat hanya memiliki gugus hidroksil 2, semakin banyak gugus hidroksil, maka semakin reaktif digunakan sebagai antioksidan, selain itu asam galat juga merupakan turunan fenolik sederhana.

Tabel 4. Pengukuran absorbansi baku asam galat

\begin{tabular}{ccc}
\hline No & Konsentrasi Asam Galat $(\mathrm{ppm})$ & Absorbansi $765 \mathrm{~nm}$ \\
\hline 1 & 0 & 0,012 \\
2 & 100 & 0,138 \\
3 & 200 & 0,307 \\
4 & 300 & 0,497 \\
5 & 400 & 0,700 \\
6 & 500 & 0,882 \\
\hline
\end{tabular}

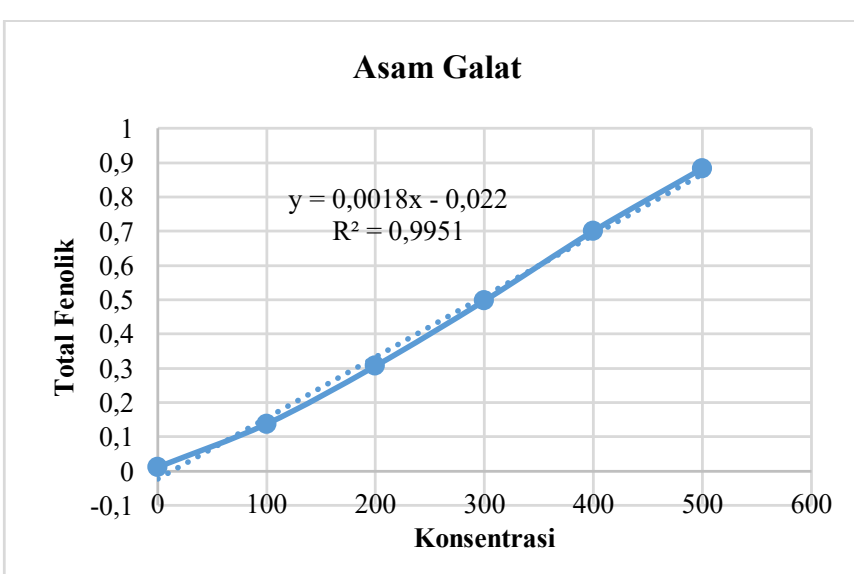

Gambar 2. Kurva linear asam galat dengan absorbansi

Pada penentuan kadar fenolik total, larutan standar yang digunakan adalah asam galat dengan variasi konsentrasi 0, 100, 200, 300, 400, 500. Hasil pengukuran absorbansi pembanding asam galat diplotkan terhadap konsentrasinya, sehingga diperoleh kurva linear seperti pada Gambar 2. Nilai
$\mathrm{R}^{2}$ yaitu 0,9951 menunjukkan linearitas yang cukup baik, maka persamaan regresi linear $(y=0,0018 x-0,022)$ dapat digunakan untuk penetapan kadar fenolik total sampel bunga rosella (Hibiscus sabdariffa L.)

\subsection{Pengukuran Kadar Air Dendeng Sapi}

Kadar air merupakan faktor pengontrol tingkat oksidasi pada produk dendeng kering oven. Kadar air sangat penting dalam menentukan daya awe dari bahan makanan karena mempengaruhi sifat fisik, kimia, perubahan mikrobiologi, dan perubahan enzimatis. Kandungan air dalam bahan makanan ikut menentukan penerimaan konsumen, kesegaran, dan daya tahan bahan. Kandungan air yang tinggi dalambahan menyebabkan daya tahan bahan rendah. Guna memperpanjang daya tahan suatu bahan, sebagian air dalam bahan harus dihilangkan dengan berbagai cara tergantung dari jenis bahan (Winarno, 2008).

Tabel 5. Hasil pengukuran nilai rata-rata kadar air dendeng sapi yang di curing menggunakan ekstrak kelopak bunga rosella.

\begin{tabular}{clc}
\hline No & Jenis Sampel & Kadar Air $(\%$ b/b dalam g/g) \\
\hline 1 & Kontrol Negatif & 23,593 \\
2 & Kontrol Positif & 16,331 \\
3 & $40 \%$ & 27,578 \\
4 & $60 \%$ & 32,058 \\
\hline
\end{tabular}

Berdasarkan Tabel 5, menunjukkan bahwa nilai rata-rata kadar air dendeng sapi dalam penelitian ini berkisar antara 16,331-32,058\%. Kadar air dendeng sapi tertinggi dalam penelitian ini didapatkan pada sampel $\mathrm{R}_{3}$ dengan penambahan ekstrak rosella $60 \%$ yaitu sebesar $32,058 \% \mathrm{~b} / \mathrm{b}$ dalam $\mathrm{g} / \mathrm{g}$ diikuti dengan penambahan ekstrak rosella $40 \%$ pada sampel $\mathrm{R}_{2}$ dan perlakuan $\mathrm{R}_{0}$ tanpa penambahan nitrat dan ekstrak rosella yaitu sebesar $27,578 \%$ dan $23,593 \%$ dan kadar air terendah dendeng sapi didapatkan pada perlakuan $\mathrm{R}$ dengan penambahan nitrat yaitu $16,331 \%$. Kadar air yang terlalu tinggi dalam bahan pangan akan mengakibatkan tumbuhnya mikroorganisme dalam bahan pangan tersebut, oleh karena itu kadar air dalam dendeng harus diperhatikan agar sesuai dengan SNI. Semakin rendah nilai kadar air dalam bahan pangan maka bahan pangan tersebut tidak akan mudah mengalami oksidasi lemak yang mengakibatkan kerusakan dalam bahan tersebut. Nitrat yang ditambahkan dalam pembuatan dendeng sapi ini lebih efektif untuk menurunkan kadar air dalam dendeng sapi dibandingkan dengan penambahan ekstrak rosella dalam konsentrasi $40 \%$ dan $60 \%$, karena memiliki nilai kadar air yang tidak terlalu tinggi. Tingginya nilai kadar air dendeng sapi pada sampel dengan penambahan ekstrak rosella $40 \%$ dan $60 \%$ tidak menunjukkan nilai terbaik untuk dendeng sapi karena tidak sesuai dengan SNI

Akan tetapi menurut penelitian-penelitian yang telah dilakukan rentangan nilai kadar air dengan penambahan ekstrak rosella $40 \%$ dan $60 \%$ masih layak digunakan dalam bahan pangan hal ini diperkuat oleh penelitian yang dilakukan oleh (Koswara, 2009) yang menyatakan bahwa kandungan air dendeng berkisar $15-50 \%$, bersifat plastis dan tidak terasa kering. Dendeng tergolong dalam produk pangan semi basah, menurut Huang dan Nip (2001) produk pangan semi basah memiliki kadar air sebesar 15\%-50\%. Berdasarkan SNI 2908:2013 maksimum nilai kadar air dendeng sapi yaitu 12\% nilai ini tanpa bahan tambahan yang telah digunakan dalam pembuatannya. Nilai kadar air akan meningkat setelah ditambahkan bahan tambahan lain seperti rosella dan bumbu-bumbu seperti gula merah, bawang putih, lada, dan ketumbar. Kadar air yang terkandung dalam dendeng sapi ini dipengaruhi oleh kadar gula yang sudah ditambahkan dalam bahan. Apabila gula diberikan pada jumlah tertentu belum tentu akan mengurangi kadar air dari bahan yang diawetkan. Gula memegang peranan yang penting dalam pengolahan dan pengawetan bahan pangan terutama daging dan apabila gula ditambahkan dalam bahan pangan dalam konsentrasi yang tinggi dalam padatan terlarut maka sebagian air yang ada menjadi tidak tersedia untuk pertumbuhan mikroorganisme.

Tingginya kadar air dendeng hasil penelitian ini juga dapat disebabkan oleh beberapa faktor antara lain, jenis dan bagian daging yang digunakan, metode pengeringan, kelembaban udara, dan suhu penyimpanan. Tingginya kadar air dendeng ini menyebabkan mudah berkembangnya mikroorganisme dalam dendeng sehingga dendeng cepat mengalami kerusakan, oleh karena itu kadar air dendeng harus diperhatikan agar sesuai dengan syarat mutu yang ditetapkan oleh SNI. Kadar air dalam daging berkisar antara 60-70\% dan apabila bahan(daging) mempunyai kadar air tidak terlalu tinggi atau tidak terlalu rendah yaitu antara kisaran $15-50 \%$ maka bahan (daging) tersebut dapat tahan lama selama penyimpanan. Jadi nilai terbaik kadar air dendeng sapi dalam penelitian ini terdapat pada perlakuan $\mathrm{R}_{1}$ dengan penambahan nitrat yaitu $16,331 \%$ karena nilainya mendekati syarat yang ditentukan oleh SNI yaitu $12 \%$.

\subsection{Pengukuran Nilai pH Dendeng Sapi}

Derajat keasaman $(\mathrm{pH})$ merupakan tingkatan asam basa suatu larutan yang diukur dengan skala 0 sampai dengan 14. $\mathrm{pH}$ digunakan untuk menyatakan tingkat keasaman atau basa yang dimiliki oleh suatu zat, larutan atau benda. $\mathrm{pH}$ normal memiliki nilai 7 sementara bila nilai $\mathrm{pH}>7$ menunjukkan zat tersebut memiliki sifat basa sedangkan nilai $\mathrm{pH}<7$ menunjukkan keasaman pH 0 menunjukan nilai keasaman yang tinggi sedangkan $\mathrm{pH} 14$ menunjukan nilai kebasaan tertinggi. 
Berdasarkan Tabel 6, menunjukkan bahwa rata-rata $\mathrm{pH}$ dendeng sapi dalam penelitian ini berkisar antara 3,6-5,3. Nilai rataan tertinggi $\mathrm{pH}$ dendeng sapi didapatkan pada sampel $\mathrm{R}_{3}$ dengan penambahan ekstrak rosella sebesar $60 \%$ yaitu 3,6 , kemudian diikuti dengan perlakuan $\mathrm{R}_{2}$ dengan penambahan ekstrak rosella $40 \%$ dan $\mathrm{R}_{0}$ tanpa penambahan nitrat dan ekstrak rosella yaitu 4,4 dan 5,2.

Tabel 6. Hasil pengukuran nilai kadar air dendeng sapi yang dicuring menggunakan ekstrak kelopak bunga rosella (Hibiscus sabdariffa L).

\begin{tabular}{clc}
\hline No & Jenis Sampel & Nilai $\mathrm{pH}$ \\
\hline 1 & Kontrol Negatif & 5,2 \\
2 & Kontrol Positif & 5,3 \\
3 & $40 \%$ & 4,4 \\
4 & $60 \%$ & 3,6 \\
\hline
\end{tabular}

Nilai $\mathrm{pH}$ terendah didapatkan pada perlakuan $\mathrm{R}_{1}$ dengan penambahan nitrat yaitu sebesar 5,3. Dengan demikian tingginya nilai $\mathrm{pH}$ ini menunjukkan sifat yang sangat asam karena nilai 3,6 berada pada $\mathrm{pH}<7$, nilai yang asam ini akan mempengaruhi cita rasa dan aroma pada dendeng, oleh karena itu nilai $\mathrm{pH}$ dendeng sapi harus sesuai SNI. Menurut Standar Nasional Indonesia (SNI) No. 01-6366-2000 merekomendasikan batas maksimal pH akhir yang tercapai mempunyai pengaruh yang berarti dalam mutu daging. $\mathrm{pH}$ rendah $(5,1-6,1)$ menyebabkan daging mempunyai struktur terbuka sehingga sangat baik untuk pengasinan, berwarna merah muda cerah sehingga disukai oleh konsumen, mempunyai flavour yang lebih disukai dan mempunyai stabilitas yang lebih baik terhadap kerusakan oleh mikroorganisme. pH tinggi (6,2-9,0) menyebabkan daging mempunyai struktur tertutup atau padat dengan warna merah ungu tua, rasa kurang enak dan keadaan yang lebih memungkinkan untuk perkembangan mikroorganisme. Nilai $\mathrm{pH}$ dendeng sapi yang mendekati SNI terdapat pada perlakuan $\mathrm{R}_{0}$ tanpa penambahan nitrat dan ekstrak rosella yaitu 5,2 diikuti dengan perlakuan $\mathrm{R}_{1}$ dengan penambahan nitrat yaitu 5,3. Dendeng hasil penelitian ini memiliki rentang nilai $\mathrm{pH}$ yang lebih lebar dari penelitian-penelitian sebelumnya.

Dalam penelitian ini nilai terbaik $\mathrm{pH}$ dendeng sapi dilihat pada sampel kontrol positif dan sampel dengan penambahan ekstrak rosella $40 \%$ dan $60 \%$, sampel kontrol positif memiliki nilai $\mathrm{pH}$ yang baik karena sesuai dengan standar yang digunakan dalam produk makanan, akan tetapi tidak menutup kemungkinan dendeng dengan rasa yang asam juga akan banyak disukai konsumen, oleh karena itu perlu dilakukan uji organoleptik dalam dendeng sapi tersebut. Beberapa penelitian menuliskan bahwa nilai $\mathrm{pH}$ untuk dendeng berkisar 5.13-5.88 sesuai dengan penelitian yang dilakukan oleh Suharyanto (2007). Perlakuan penambahan nitrat dan rosella masing-masing memiliki nilai $\mathrm{pH}$ yang berbeda. Dendeng dengan penambahan nitrat memiliki $\mathrm{pH}$ asam yang rendah dibandingkan dendeng dengan penambahan ekstrak rosella. Penambahan rosella hingga level $60 \%$ sangat meningkatkan keasaman dendeng.

Derajat keasaman dendeng sapi yang dihasilkan semakin tinggi seiring dengan meningkatnya konsentrasi ekstrak kelopak bunga rosella yang ditambahkan. Rosella bersifat asam karena memiliki kandungan asam sitrat dan asam malat sebesar 13\% (Maryani dan Kristiana, 2008). Bahan pangan dapat digolongkan atas beberapa kelompok berdasarkan $\mathrm{pH}$ nya yaitu bahan pangan berasam rendah $(\mathrm{pH}>5,3)$, sedang $(\mathrm{pH} 4,5-5,3)$, asam $(\mathrm{pH} 3,7-4,5)$, tinggi $(\mathrm{pH}$ $<3,7$ ). Komponen senyawa asam yang dominan pada rosela yaitu asam sitrat dan asam malat, disamping itu mengandung senyawa-senyawa asam lain seperti asam askorbat, asam maleat, asam oksalat, asam tartrat, dan asam glikolat (Maryani dan Kristiana, 2008). Berdasarkan hasil diatas pH dendeng sapi yang dicuring menggunakan ekstrak rosela, nilai $\mathrm{pH}$ akan semakin kecil dengan semakin meningkatnya konsentrasi ekstrak kelopak bunga rosella. Nilai pH yang semakin kecil menunjukan semakin meningkatnya rasa asam bahan pangan tersebut. Nilai $\mathrm{pH}$ yang rendah juga dapat mengurangi terjadinya oksidasi dalam dendeng tetapi dapat mempengaruhi cita rasa dendeng karena rasa yang semakin asam. Semakin tinggi konsentrasi ekstrak rosella yang ditambahkan dalam dendeng sapi ini maka semakin tinggi pula nilai antioksidan dalam bahan pangan yang dapat mencegah terjadinya kerusakan dalam dendeng tersebut.

\section{Simpulan}

Berdasarkan hasil penelitian dapat disimpulkan bahwa pada sampel $R_{3}$ dengan penambahan konsentrasi ekstrak rosella 60\% dapat meningkatkan nilai total fenolik dendeng sapi yaitu sebesar $0,650 \mathrm{mg} / \mathrm{g}$. Penambahan nitrat pada sampel $\mathrm{R}_{1}$ mampu menurunkan nilai $\mathrm{pH}$ dan nilai kadar air dan meningkatkan nilai antioksidan dendeng sapi, untuk nilai $\mathrm{pH}$ dendeng sapi yaitu 5,3, dan nilai kadar air 16,331\%, nilai pH dan nilai kadar air ini terbaik karena sesuai dengan SNI. Penambahan nitrat masih memegang peranan yang lebih efektif dibandingkan dengan sampel ekstrak rosella $40 \%$ dan $60 \%$.

\section{Pustaka}

Aaby K., S. Mazur., A, Nes and G, Skrede. 2012. Phenolic compounds in strawberry (Fragaria $x$ ananassa Duch.) fruits: Composition in 27 cultivars and changes duringripening. Food Chem. 132 (1): 86-97.

Abustam, E. 2000. Pengolahan dan Pengawetan Daging. Fakultas Peternakan Universitas Hasanuddin. Makassar.
Chang, C. C., M.H, Yang., H.M, Wen and J.C, Chern. 2002. Estimation of Total Flavonoid Content in Propolis by Two Complementary Colorimetric Methods. J. Food Drug Anal, 10 (3) : 178-182.

Apriadji, W. H. 2008. Beauty Salad: 81 Salad Buah dan Sayur Cita Rasa Indonesia untuk Tampil Cantik, Langsing, dan Awet Muda. Jakarta: Gramedia Pustaka Utama.

Falade, O.S., I.O, Otemuyiwa., A. Oladipo., O.O, Oyedapo., B.A, Akinpelu.,S.RA, Adewusi. 2005. The chemical composition and membrane stability activity ofsome herbs used in local therapy for anemia. J. Ethnopharmacol,102 (1):15-22.

Huang T. C, Nip W. K. 2001. Intermediate - Moisture Meat and Dehydrated Meat. Didalam : Hui YH, Nip WK, Rogers RW, Young OA, Editor. Meat Science Application. New York- Basel: Marcel Dekker. 403-442.

Koswara, S. 2009. Teknologi Praktis Pengolahan Daging. E-book Pangan.

Mardiah., S, Hasibuan., A. Rahayu dan R. W. Ashadi. 2009. Budi Daya dan Pengolahan Rosella Si Merah Segudang Manfaat. Agromedi, Jakarta Selatan.

Maryani, H dan L. Kristiana. 2008. Khasiat dan Manfaat Rosella. Agromedia Pustaka. Jakarta.

Molyneux P. 2004. The use of the stable free redical diphenylpicryl-hidrazyl (DPPH) for estimating antioxidant activity. J. Sci. Technol, 26(2): 211219.

Muchtadi, T. 2008. Ilmu Pengetahuan Bahan Pangan. IPB-Press. Bogor. Jurusan Pertanian Universitas Syiah Kuala.

Rusnayanti Y. 2018. Pengaruh suhu dan lama pengeringan terhadap mutu teh hijau daun kakao (Theobroma cacao L.). [Artikel Ilmiah]. Mataram: Fakultas Teknologi Pangan dan Agroindustri. Universitas Mataram

Selim K. A., Khalil K. E, Abdel-bary M.S., Abdel Azeim N.A. 2008. Extraction, encapsulation and utilization of red pigments from Roselle (Hibiscus sabdariffa L.) as natural food colorant. Food science and Tech. Dept.

Standar Nasional Indonesia. 2000. Daging Segar. Jakarta : Badan Standarisasi Nasional.

Suharyanto. 2007. Karakteristik Dendeng Daging Giling Pada Pencucian (Leaching) dan Jenis Daging yang Berbeda. [Tesis]. Sekolah Pasca Sarjana. Institut Pertanian Bogor, Bogor.

Sukhapat N, Ungpaiboon S, Itharat A, Puripattanavong J, Pinsuwan S, 2004. Influence of $\mathrm{pH}$ on antioxidant activity of roselle (Hibiscus sbdariffa L.) extract in aquoeus solution. The 10th World Conggress on Clinical Nutrition in the next decade: Nutraceutical/Functional food: Product Performace in Health, Disease and Safety. Abstract Book organized by PSU, INC and Biotec 30 Nov- 3 Dec, 2004. Phuket, Thailand, p.184

Suryati, T., M. Astawan., H.N Lioe dan T, Wresdiyati. 2012. Curing ingredients, characteristics, total phenolic, and antioxidant activity of commercial indonesian dried meat product (dendeng). Media Peternakan, 35(2):111-116.

Tsai, P.J., J. Mcintosh.,P. Pearse., B. Camden., B.R, Jordan. 2002. Anthocyanin and antioxidant capacity in Roselle (Hibiscus sabdariffa L) extract. Food Res.International 35 (4):351-356.

Widia, N. 2007.Evaluasi Senyawa Fenolik (Asam Ferulat dan Asam p-Kumarat Pada biji, Kecambah dan Tempe Kacang Tunggak (Vigna unguiculata). [Skripsi]. Bogor: Institut Pertanian Bogor.

Widjaya, C.H. 2003. Peran Antioksidan Terhadap Kesehatan Tubuh, Healthy Choice. Edisi IV.

Winarno FG. 2008. Kimia Pangan dan Gizi. Jakarta (ID): Gramedia Pustaka Utama. 